\title{
Global Mechanisms for Achieving Gender Equality in the Careers of Law and the Judiciary: The State of São Paulo as A Case Study
}

\author{
Renata Miranda Lima* \\ Lgo Pólvora, 141 - Liberdade - SP, Brazil \\ Raíssa Moreira Lima Mendes Musarra \\ Lgo Pólvora, 141 - Liberdade - SP, Brazil \\ Jorge Cavalcante Boucinhas \\ Lgo Pólvora, 141 - Liberdade - SP, Brazil \\ Regina Célia Martinez \\ Lgo Pólvora, 141 - Liberdade - SP, Brazil
}

The research is financed by Escola Superior da Advocacia de São Paulo - ESAOABSP

\section{Abstract}

The objective of this work is to analise the professional vertical mobility of women in the sectors of advocacy and the judiciary through a monographic method with a case study in Brazil, state of São Paulo, and research techniques based on bibliographic and documentary analysis and their relations with the achievement of SDG 5 Achieve gender equality and empower all women and girls - in particular, to ensure the full and effective participation of women and equal opportunities for leadership at all levels of decision-making in political life, economic and public, by way of proposing the construction of models and processes capable of overcoming gender inequalities in the legal professions in constituted groups. The professional mobility of women will be assessed based on the idea of material equality for the construction of models and processes capable of overcoming gender inequalities in the legal professions. Therefore, the need for equal representation, minimum of $50 \%$, is assumed in commissions, councils and boards, events and courses at OABSP headquarters. And yet, the revision of criteria such as seniority to rise to second level judicial positions in the São Paulo judiciary.

Keywords: ODS 5; Advocacy; Judiciary; Brazil; State of São Paulo.

DOI: $10.7176 /$ RHSS/11-12-02

Publication date:June $30^{\text {th }} 2021$

\section{Introduction}

This work aims to understand, in front of SDG 5, referring to gender equality, the professional mobility of women in the sectors of advocacy and the judiciary through a monographic method with a case study in Brazil, state of São Paulo, and research techniques based on the bibliographic and documentary analysis.

It is considered that the advantage of the aforementioned method consists in respecting the "total solidarity" of the groups, when studying, in the first place, the life of the group in its concrete unity, avoiding, therefore, the premature dissociation of its elements ${ }^{1}$, by way of a proposition to build models and processes capable of overcoming gender inequalities in the legal professions in the groups referred to, especially concerning ensuring the full and effective participation of women and equal opportunities for leadership at all levels of decisionmaking in political, economic and public life. Because of the persistence of gender inequality, the United Nations' fifth objective proposes that countries overcome this issue more effectively ${ }^{2}$.

In this regard, Bourdieu observes that female subordination is partly due to a process of eternalization of the arbitrary $^{3}$. This eternalization of male domination is conceived as a universal model, which is why the reproduction of this domination persists even with changes, such as the performance of the feminist movement, the increase in women's access to school and higher education, the growth of women in the labor market and its reconfiguration todays ${ }^{4}$.

Note ${ }^{1}$. Marconi, Marina de Andrade; Lakatos, Eva Maria. Fundamentos de metodologia científica. São Paulo: Atlas, 5. ed. 2003.

Note $^{2}$ Lima. Renata Mirada; Lulia, Luciana Toledo Temer. Estudo sobre gênero e raça: mobilidade no Tribunal de Justiça do Estado de São Paulo. Revista Prisma Jur., São Paulo, v. 19, n. 1, p. 2-22, jan./jun. 2020.

Note ${ }^{3}$ Bourdieu, Pierre. A dominação masculina. 1999, Rio de Janeiro, Bertrand Brasil, p.10, 100-101

Note $^{4}$ Bonelli, Maria da Gloria. Cunha, Luciana G; Oliveira, Fabiana L. de; Silveira., Maria Natália B. da. Profissionalização por gênero em escritórios paulistas de advocacia. Tempo Social, revista de sociologia da USP, v. 20, n. 1. 2008, p. $270-271$. 


\section{Participation in decision-making positions and representation in the legal profession (OAB / SP)}

Brazilian law, which, until 7/13/2020, had 597,593 lawyers and 603,027 active lawyers in Brazil, still holds the data that women are a minority in company command posts and law firms ${ }^{1}$. Until 2020, the Brazilian Federal Bar Association never had women in ${ }^{2}$ office and the decision-making positions of the OAB were held only by men. According to María Inés Bergoglio, this is a phenomenon that is repeated in Latin America, just: "A view inside these modern organizations reveals, however, a worrying trend: gender inequalities are significant in them. As more information is given, the presence of women is very low in hierarchical levels, a fact that calls attention to a country where the female contingents in the profession exceed $42 \%$ (2001 Census)" 3 .

According to Maria Glória Bonelli, a factor that benefits lawyers to the detriment of lawyers in the professionalization process is the "social capital", which is in the domain of men because they have been in the career for a longer time, since it was born under the predominance of men. Although "academic capital is shared by both genders", entry into the profession and progression in it depend on "access to hegemonic groups of power that act as mentors and notables"4.

Because there are few women positioned at the top of the profession, they have more difficulty forming networks. "Besides, reaching the partner position requires social capital to recruit new business customers and charge more hours for services rendered" ${ }^{5}$. These requirements are exercised in an unbalanced manner due to family activities that mostly fall to women. Thus, career advancement for women still holds obstacles, which contributes to the formation of less prestigious segments in law. Finally, as a way of completing the reasoning, Bonelli notes that some segments and organizations in the areas of law are mostly composed of women ${ }^{6}$.

In general, areas that deal with less unforeseen circumstances and with "routine tasks, whose load is adjustable to the planning of time and time, involve less specialization, training and updating"7 are relegated to them, reinforcing the devaluation of the lawyers' social capital ${ }^{8}$. From the survey carried out by the Permanent Commissions (total 14) and Special Commissions (total 105) of the Order of Lawyers of Brazil São Paulo Section, it is possible to observe the presence of women in almost all of them, noting, however, that of the 105 Special Commissions, 50 Commissions hold positions in the presidency or vice-presidency of Women; and that commissions related to the relationship between the $\mathrm{OAB}$ and justice institutions have low female participation.

Of the fourteen Standing Committees, only 05 (five) women occupy Presidency positions, all in the function of Vice, that is, secondary, in the following commissions: Public Advocacy, Environment, Lawyer, Budget and accounts and Committee of the Mediation Chamber, conciliation and arbitration. It is worth noting the low number of committees, in which the number of lawyers does not reach one-third of participants, including issues related to business, military, electoral law, and institutional relations with other institutions and powers.

Committees with parity or above-average participation are included in topics related to family relationships (family law and adoption), minorities or minority majorities (children and adolescents, the elderly, the disabled, racial equality, female lawyers and women's candidacy observatory), rights social and collective (social security, labor, third sector, and related to the environment and urban planning, animal rights) and alternative solutions for litigation or compliance, collaborative practices, and coaching. Out of these groups, representations in the digital law commission (43 out of 44 participants), and in graduate and research undergraduate studies (33 out of 48) stand out.

It is worth noting the approval by the Federal Council of the OAB on February 10, 2020, unanimously, of a proposal that requires the presence, in all events held within the scope of the Council and its respective Commissions, as a speaker, of a minimum of $30 \%$ and a maximum of $70 \%$ of members of each gender ${ }^{9}$. The OAB of São Paulo expressed adherence to this initiative, still without formalization. The composition in the Federal Council for the 2019-2021 triennium has only 17 women, out of a total of 81 councilors, completely distancing from the recommended parity.

The structure of the OAB - SP for the same three-year period includes a male President, Vice-President and Secretary-General, and a Deputy Secretary-General and female Treasurer ${ }^{10}$. Also, the OAB Federal and the OAB

Note ${ }^{1}$ Bonelli, Maria da Gloria. Cunha, Luciana G; Oliveira, Fabiana L. de; Silveira., Maria Natália B. da. Profissionalização por gênero em escritórios paulistas de advocacia. Tempo Social, revista de sociologia da USP, v. 20, n. 1. 2008, p. 270-271.

Note $^{2}$ BRASIL. OAB Federal. Ex presidents.

Note $^{3}$ Bergoglio, María Inés ¿Llegar a socia? La movilidad ocupacional en las grandes empresas jurídicas Análisis de género. p 2-3, 2007.

Note $^{4}$ Bonelli, Maria da Gloria. Cunha, Luciana G; Oliveira, Fabiana L. de; Silveira., Maria Natália B. da. Profissionalização por gênero em escritórios paulistas de advocacia. Tempo Social, revista de sociologia da USP, v. 20, n. 1. 2008, p. 270-271.Idem

Note ${ }^{5}$ Idem

Note ${ }^{6}$ Bonelli, Maria da Gloria. Cunha, Luciana G; Oliveira, Fabiana L. de; Silveira., Maria Natália B. da. Profissionalização por gênero em escritórios paulistas de advocacia. Tempo Social, revista de sociologia da USP, v. 20, n. 1. 2008, p. 270-271.

Note $^{7}$ Idem

Note ${ }^{8}$ Ibidem

Note ${ }^{9}$ OABSP Proposition: 49.0000.2019.013134-1/COP. OAB fixa mínimo de 30\% de mulheres como palestrantes em eventos.

Note ${ }^{10}$ OABSP. Diretoria OABSP. 
of São Paulo joined, in 2019, the United Nations Global Pact ${ }^{1}$, thus signing the already described principle of "Stimulating practices that eliminate any type of discrimination in employment", which, here understood, it represents the concept of "work" in a broad sense.

Thus, it is expected that parity at all levels will be considered a vector in the search for non-discrimination. A scenario of discrimination is corroborated in the data referring to the second instance of the magistracy of the State of São Paulo, where, in 2017, the first instance consisted of 373 judges and 340 judges in the capital, while the second instance is composed of 361 judges and 28 judges $^{2}$. In other words, although there is a majority of women at first instance, this does not reproduce equally in the Superior Courts and positions of power of the institutions.

What is happening in the creation of sophisticated means of perpetuating gender discrimination planted in the past. According to research carried out in the State of São Paulo, the main way of maintaining the professional immobility of female judges is through the constitutional rule that, for career mobility at the second instance, requires seniority and merit. This rule of formal equality does not observe the starting point of the subjects, because it ignores that women entered 106 years later in the first instance magistracy due to gender discrimination ${ }^{3}$. It is noteworthy that this form of discrimination, despite being found only in the State of São Paulo, is replicated in all Brazilian states, since it is a constitutional rule. Added to this application of constitutional rule throughout the national territory is the fact that women had access to higher education later than men due to legal impediment, given that in Brazil, the right to higher education was only achieved by women at the end of the 19th century, by Decree number 7,247, of April 1879, edited by Dom Pedro II ${ }^{4}$.

The impossibility of access to higher education by women was a practice that was reproduced by several countries as a key mechanism to make women's social mobility impossible and, thus, to maintain a social, economic, and professional dependence, since their activities were restricted to the activities of the home or the profession exercised by the partner. Therefore, even though legal impediments do not exist today, they have generated different starting points, which can only be remedied when verified and applied to subjects in different ways. Otherwise, women will always be deferred from accessing positions that require higher education, as is the case with the judiciary.

In harmony with the above, Bourdieu affirms that the new female condition continues to obey the logic of the model between male and female, which is fed by habits, a "system of dispositions acquired in socialization", which functions as organizers of practices in society and representations. Symbolic violence uses the androcentric categories, "which are inscribed on things and bodies as lasting structures for the eternalization of relations of domination" that are legitimized as subordination ${ }^{5}$.

These gender inequalities in legal careers are also present on the European continent and, in this regard, the research carried out by Anne Boigeol that highlights the difficulties of implementing gender equality in access and promotion in the judiciary in France and Portugal stands out ${ }^{6}$. Thus, the authors propose the presentation of the analysis of the relationships between access to social good for higher education for men and women and social mobility of unequal rise in legal careers, to collaborate to the verification of the persistence of inequalities in contemporary times and, results, present proposals to overcome barriers to entry and professional mobility of women in the legal careers of the legal profession and the judiciary.

\section{Women and the judiciary in Brazil and São Paulo}

Despite the achievements of women in accessing spaces in the Brazilian judiciary, according to the data, the Brazilian judiciary is still mostly composed of male magistrates and women represent a very small percentage in the higher courts.

To reflect on this situation and understand the intersections of violence that maintain this inequality, the present topic must reflect the Brazilian judiciary and its composition about gender, having as its main field of study the higher courts and the second instance which is exercised by judges and judges.

In this regard, it is important to highlight that the judge is the magistrate who acts in the second instance,

Note ${ }^{1}$ On May 23, 2019, the National President of the OAB, Felipe Santa Cruz, forwarded a letter to the UN Secretary-General, António Guterres, requesting the $\mathrm{OAB}$ to join the Global Compact and making a commitment to comply with the principles of the agreement, related to Human Rights, Labor Rights, Environmental Protection and Anti-Corruption.

Note $^{2}$ Lima. Renata Mirada; Lulia, Luciana Toledo Temer. Estudo sobre gênero e raça: mobilidade no Tribunal de Justiça do Estado de São Paulo. Revista Prisma Jur., São Paulo, v. 19, n. 1, p. 2-22, jan./jun. 2020

Note ${ }^{3}$ Idem.

Note $^{4}$ São Paulo. Decreto $n^{\circ} 7.247$ de 19 de abril de 1879. Reforma o ensino primário e secundário no municipio da corte e o superior em todo império. 1879

Note ${ }^{5}$ Bourdieu, Pierre. A dominação masculina. 1999, Rio de Janeiro, Bertrand Brasil.

Note ${ }^{6}$ Boigeol, Anne. Las mujeres y la corte. La dificil implementación de la igualdad de sexos en el acceso a la magistratura. Revista sobre Enseñanza del Derecho de Buenos Aires, Año 3, número 6, 2005, p. 03-25. Boigeol, Anne. Feminisation of the French Magistrature, between Parity and Disparities. Conferência realizada a 18.06.2013, na Assembleia da República de Lisboa - Portugal, no âmbito da sessão "As mulheres nas profissões jurídicas: experiências europeias" do Colóquio "As mulheres nas magistraturas: percursos e desafios". 2013. 
that is, he is a member of the Courts of Justice, Federal Regional Courts and Regional Labor Courts. This judge judges appeals against judgments handed down at First Instance. The career judge can be promoted to judge by the criteria of seniority or merit provided for in article 94 of the Constitution of Brazil. There is also the criterion of the Fifth Constitutional in which $20 \%$ of the members of the Courts of Justice must be composed of members of the Public Ministry (MP) and the Advocacy (according to article 94 of the Federal Constitution ${ }^{1}$ ).

It appears that by $2018,38.8 \%$ of magistrates working in Brazil observing the different areas of law in the judiciary. Female participation in the judiciary is even lower when considering the magistrates who served in the last 10 years, with $37.6 \%$ women. Although still low, there was an increase in the percentage of magistrates concerning the composition of the Judiciary in 1988, when women occupied $24.6 \%$ of the positions of magistrates. It is important to keep in mind the female population and the male population of the country so that it is possible to make comparisons. According to the Brazilian Institute of Geography and Statistics (IBGE), the Brazilian population is made up of $51.6 \%$ female and $48.4 \%$ male. Thus, men are predominant in the judiciary, given that they represent $48.4 \%$ of the population, but account for $61.2 \%$ of judges in Brazil ${ }^{2}$.

It appears that the inequality scenario is deepened in terms of positions, given that female participation in the judiciary is even lower. According to data, the percentage of magistrates in the positions of Judges, Corregedoras, Vice-Presidents and Presidents has increased about the last 10 years, however, they remain at the level of $25 \%$ to $30 \%$. About Substitute Judges, the number of women was even closer to that of men (from $41.9 \%$ to $45.7 \%$ ).

The only case of retraction in the participation of women occurred between the summons of judges to act in the courts - from $32.9 \%$ to $31.1 \%{ }^{3}$. Funneling the study to the State of São Paulo, it is noteworthy that this State concerning the higher levels of state, federal, military, electoral, and labor justice also presents a plural framework, however, it reproduces the same scenario in which women are a minority in positions dome of the courts.

According to a survey on the website of the Court of Justice of the State of São Paulo, there are 358 judges in 2020. Of these, 287 are through competition, of which there are 20 women, 36 have entered through the Public Ministry and there are 3 women and 35 people who have entered the Court of Justice of the State of São Paulo for advocacy and of this group 8 are women ${ }^{4}$. Also according to the Constitution, one third of the STJ's ministers must be chosen from judges of the federal regional courts, one third from the judges of the state courts of law and one third, in equal parts, from lawyers and members of the Public Ministry.

The names to be chosen are indicated by the STJ Plenary, in a triple list system that presents the candidates according to the decreasing order of the votes obtained in a public session of the Court. In any choice, the representative must have more than ten years of effective professional activity ${ }^{5}$. Currently the STJ is composed of 33 ministers, of which only 6 are women ${ }^{6}$.

Finally, it is necessary to highlight the Supreme Federal Court, which is the summit of the Judiciary, which is primarily responsible for guarding the Constitution, as defined in art. 102 of the Constitution of the Republic. This court is composed of eleven Ministers, all born Brazilians (art. 12, § 3, inc. IV, of the CF / 1988) ${ }^{7}$, chosen from citizens over 35 and under 65 years of age, of remarkable legal knowledge and reputation cleared (art. 101 of the CF / 1988), and appointed by the President of the Republic, after approval of the choice by the absolute majority of the Federal Senate (art. 101, sole paragraph, of the CF / 1988). This is composed of 11 ministers, of whom only 2 are women ${ }^{8}$.

\section{Conclusion}

It is considered that the construction of the figure of the woman in the world is linked to the hierarchy between the sexes from the social construction of the gender figure that forms the social imaginary. This imaginary, over the years, has undergone changes that forced the expansion of social spaces so that women could also obtain space.

However, the base that hierarchizes society remains, so the distribution of these spaces is still uneven, given that the inequalities planted in the past still reflect in the present. An example of the above is the access to education that, despite being equitable in contemporary times, non-access in the past still reflects on the disparity in the number of women in command positions in the labor market, whether in the public or private sphere.

Specifically in advocacy, what happens is the reproduction of this scenario, but it takes on a different shape,

Note ${ }^{1}$ Tribunal De Justiça Do Estado De São Paulo. Órgãos do Poder judiciário, 2020.

Note $^{2}$ Conselho Nacional Da Justiça. Diagnóstico da participação feminina no Poder Judiciário. 2019 , p .7.

Note ${ }^{3}$ Idem.

Note $^{4}$ São Paulo. Lista de antiguidade dos desembargadores do estado de São Paulo, 2020.

Note $^{5}$ Superior Do Tribunal De Justiça. Ministros, 2020.

Note ${ }^{6}$ Idem.

Note ${ }^{7}$ Ibidem

Note ${ }^{8}$ Superior Do Tribunal De Justiça. Ministros, 2020. 
given that women access the law with equality between the sexes, but the unequal logic is revealed when we focus our attention on verifying where these women are. According to the studies, these are concentrated in grassroots positions and in areas of law that work in small and less complex cases. While men are concentrated in areas considered in the more complex legal world, involved in the economic market, therefore, with higher remuneration and social prestige.

Nevertheless, the global composition of the commissions has pointed to an increasingly emancipatory trend from the point of view of areas such as Collective Rights, Digital Law, and the Postgraduate and Research commission. Despite this, participation in committees in the OABSP is insufficient in decision-making positions, with chairpersons of permanent committees relegated to a third of women, and the total number of vicepresidents in half of the special committees (with no chairmanship),

In the meantime, it is considered that the data presented points to the understanding of the continuity of the existence of the logic of reproduction of gender inequality, indicating the formulation of effective public policies to eliminate all forms of inequality of people due to sex in national and local level and the encouragement of internal practices of professional legal institutions towards achieving the SDG 5 regarding female empowerment.

Therefore, the need for equal representation, a minimum of $50 \%$, is assumed in commissions, councils, and boards, events, and courses at OABSP headquarters. And yet, the revision of criteria such as seniority to rise to second level judiciary positions in the São Paulo judiciary, combined with parity efforts in the constitutional fifth for constitutionally occupying positions. Such parity should preferably be accompanied by a nationally compatible move, seeking to meet the objectives and principles assumed in the 2030 Agenda.

\section{References}

Boigeol, Anne. Las mujeres y la corte. La dificil implementación de la igualdad de sexos en el acceso a la magistratura. Revista sobre Enseñanza del Derecho de Buenos Aires, Año 3, número 6, 2005.

Boigeol, Anne. Feminisation of the French Magistrature, between Parity and Disparities. Conference held on 06/18/2013, in the Assembly of the Republic of Lisbon - Portugal, within the scope of the session "As mulheres nas profissões jurídicas: experiências europeias" of the Colloquium "As mulheres nas magistraturas: percursos e desafios". 2013.

Bourdieu, Pierre. A dominação masculina. 1999, Rio de Janeiro, Bertrand Brasil. La movilidad ocupacional en las grandes empresas jurídicas Análisis de género, 2007.

Bonelli, Maria da Gloria. Cunha, Luciana G; Oliveira, Fabiana L. de; Silveira., Maria Natália B. da. Profissionalização por gênero em escritórios paulistas de advocacia. Tempo Social, revista de sociologia da USP, v. 20, n. 1. 2008

Brasil. OAB Federal. Ex presidents, 2020.

Le Feuvre, Nicky Le \& Lapeyere, Nathalie. Les 'scripts sexués' de carrière dans les professions juridiques en France. Knowledge, Work \& Society, 1 (3), 2005, p. 113, The feminization of the professions: thematic issue. (org. Mirella Giannini).

Lima. Renata Mirada; Lulia, Luciana Toledo Temer. Estudo sobre gênero e raça: mobilidade no Tribunal de Justiça do Estado de São Paulo. Revista Prisma Jur., São Paulo, v. 19, n. 1, p. 2-22, jan./jun. 2020.

Marconi, Marina de Andrade; LAKATOS, Eva Maria. Fundamentos de metodologia científica. São Paulo: Atlas, 5. ed. 2003.

OAB Federal - Ordem dos Advogados do Brasil. Quadro de advogados por gênero, 2020.

OAB Federal - Ordem dos Advogados do Brasil. Ordem dos Advogados do Brasil Proposition: 49.0000.2019.013134-1/COP. OAB fixa mínimo de 30\% de mulheres como palestrantes em eventos.

Migalhas Quentes. Conselho Federal da OAB para o próximo triênio já está formado, 2020.

Ordem dos Advogados do Brasil, Seccional São Paulo. Diretoria OABSP, 2020. 